\title{
Response of Wheat (Triticum aestivum L.) under Drip Fertigation System
}

\author{
B.A. Karangiya* , H.H. Mashru and H.M. Vadher \\ Department of Soil and Water Conservation Engineering, College of Agricultural Engineering \\ and Technology, Junagadh Agricultural University, Junagadh, India \\ *Corresponding author
}

\begin{abstract}
A B S T R A C T
The experiment was carried out in winter season of 2017-18 (November-March) at Instructional Farm, College of Agricultural Engineering and Technology, JAU, Junagadh

Keywords

Drip Irrigation, Fertigation, FUE, Wheat, WUE

Article Info

Accepted:

20 May 2019

Available Online:

10 June 2019 to study the response of wheat (Triticum aestivum L.) under drip fertigation system. The experiment was undertaken with four fertigation levels viz., 40\% RDF-N $\left(\mathrm{F}_{1}\right), 60 \%$ RDF$\mathrm{N}\left(\mathrm{F}_{2}\right), 80 \%$ RDF-N $\left(\mathrm{F}_{3}\right)$ and $100 \%$ RDF-N $\left(\mathrm{F}_{4}\right)$ and three irrigation level viz., 0.6 IW/ETc $\left(\mathrm{I}_{1}\right), 0.8 \mathrm{IW} / \mathrm{ETc}\left(\mathrm{I}_{2}\right)$ and $1.0 \mathrm{IW} / \mathrm{ETc}\left(\mathrm{I}_{3}\right)$. Large plot technique was adopted with three replications of each treatment. Fertigation levels and irrigation levels were taken as a main and sub factor respectively. Higher plant height at harvesting, grain yield, straw yield and yield attributes were observed at fertigation level 100\% RDF-N and irrigation level 1.0 $\mathrm{IW} / \mathrm{ET}_{\mathrm{C}}$ but, it was found that $0.8 \mathrm{IW} / \mathrm{ET}_{\mathrm{C}}$ statistically at par with $1.0 \mathrm{IW} / \mathrm{ET}_{\mathrm{C}}$. So, optimum irrigation level for wheat under drip irrigation system is $0.8 \mathrm{IW} / \mathrm{ET}_{\mathrm{C}}$. Higher fertilizer use efficiency of $84.58 \mathrm{~kg} / \mathrm{kg}$ was observed at fertigation level $40 \% \mathrm{RDF}-\mathrm{N}\left(\mathrm{F}_{1}\right)$ combination with irrigation level 1.0 IW/ETc $\left(\mathrm{I}_{3}\right)$. Higher water use efficiency 17.12 $\mathrm{kg} / \mathrm{ha}-\mathrm{mm}$ was observed at irrigation level $0.6 \mathrm{IW} / \mathrm{ETc}\left(\mathrm{I}_{1}\right)$ combination with fertilizer level $100 \%$ RDF-N $\left(\mathrm{F}_{4}\right)$.
\end{abstract}

\section{Introduction}

Wheat (Triticum aestivum L.) is one of the most important staple food grains of human race. India stands $2^{\text {nd }}$ both in area $29.65 \mathrm{M}$ ha and production 86.5 MT with average productivity of 3 tons per hectare in the world. India's share in world wheat area is about $12.5 \%$ whereas it occupies $12.05 \%$ share in the total world wheat production.

It is the second largest producer of wheat in the world. In India, most of the area under wheat crop is irrigated by flood irrigation with very poor water use efficiency. Available estimates indicate that water use efficiency under flood method of irrigation is only about 35 to 40 per cent because of huge conveyance and distribution losses (Rosegrant, 1997; INCID, 1994). India's water resources, particularly in the context of agriculture, are facing extreme stress.

In India, availability of irrigation water is the major limiting factor in improving wheat productivity. India has the largest irrigated area in the world, two decades ago, more than 60 per cent of wheat in India was grown 
under rain fed situation. At present, more than 60 per cent of wheat area is under irrigated condition, of which about 50 per cent receive only one or two irrigations (Chouhan and Yadav, 2012). One of the main reasons for the low coverage of irrigation is the predominant use of flood (conventional) method of irrigation, where water use efficiency is very low. There is need to improve irrigation efficiency through optimization of irrigation water under conditions of limited water availability.

Considering the water availability for future use and the increasing demand for water from different sectors, a number of demand management strategies and programmes have been introduced since late seventies in India to increase the water use efficiency, especially in the use of surface irrigation water. One of the demand management strategies introduced recently to control water consumption in Indian agriculture is micro irrigation (MI), which includes mainly drip and sprinkler irrigation method. Among all the irrigation methods, the drip irrigation is the most efficient.

With increasing demand of irrigation water, the irrigation efficiency and water use efficiency can be enhanced by replacing surface irrigation with micro irrigation methods especially in arid and semi-arid region.

The overall irrigation efficiency of micro irrigation system normally ranges from 70$90 \%$ as compare to $30-45 \%$ in case of surface irrigation owing to reduce loss of moisture through evaporation/runoff. Drip irrigation is considered the most efficient method because it applies water precisely and uniform at high frequency and maintained high soil metric potential in the root zone, additionally well aerated condition can be maintaining in drip irrigation.
Wheat is very sensitive to insufficient nitrogen and very responsive to nitrogen fertilization. Insufficient $\mathrm{N}$ availability to wheat plants results in low yields and significantly reduced profits compared to a properly fertilized crop (Singh et al., 2010). Fertigation has the potential to supply a right mixture of water and nutrients to the root zone, and thus meeting plants' water and nutrient requirements in most efficient possible manner.

The introduction of simultaneous microirrigation and fertilizer application (fertigation) opens new possibilities for controlling water and nutrient supplies to crops besides maintaining the desired concentration and distribution of nutrients and water into the soil (Bar-Yosef, 1999). By introducing drip with fertigation, it is possible to increase the yield of crops by 3 times from the same quantity of water. When fertilizer is applied through drip, it is observed that beside the increase in yield, about 30 per cent of the fertilizer could be saved (Sivanappan and Ranghaswami, 2005).

\section{Materials and Methods}

To achieve the objectives of the study, field experiment was carried out in winter season of 2017-18 (November-March) at Instructional Farm, College of Agricultural Engineering and Technology, JAU, Junagadh located at $21.5{ }^{\circ} \mathrm{N}$ latitude and $70.1{ }^{\circ} \mathrm{E}$ longitude with an altitude of 60 meter above mean sea level. The study area having typically subtropical and semi-arid climate. The soil of the experimental plot was clay in texture and slightly alkaline in reaction. The soil had organic carbon content of $0.90 \%$, and it had $23.77 \%$ field capacity and $2.5 \mathrm{~g} / \mathrm{cc}$ specific gravity. It had dry bulk density of $1.37 \mathrm{~g} / \mathrm{cc}$. Sowing of wheat seed at a seed rate of $120 \mathrm{~kg} / \mathrm{ha}$ and $22.5 \mathrm{~cm}$ row to row spacing was done on $17^{\text {th }}$ November, 2017 by tractor 
mounted seed cum fertilizer drill. The recommended dose of phosphorus @ $60 \mathrm{~kg}$ $\mathrm{P}_{2} \mathrm{O}_{5} \mathrm{ha}^{-1}$ and potassium @ $60 \mathrm{~kg} \mathrm{~K}_{2} \mathrm{O} \mathrm{ha}{ }^{-1}$ were applied as basal dose in the form of single super phosphate and muriate of potash, respectively. Nitrogen (urea) was applied at weekly interval up to 64 days as per treatments. The weekly dose of nitrogen was applied as per following percentage during various growth stage.

The experiment was undertaken with four fertigation levels viz; 40\% RDF-N $\left(\mathrm{F}_{1}\right), 60 \%$ RDF-N $\left(\mathrm{F}_{2}\right), \quad 80 \%$ RDF-N $\left(\mathrm{F}_{3}\right)$ and $100 \%$ RDF-N $\left(\mathrm{F}_{4}\right)$ and three irrigation level viz; 0.6 $\mathrm{IW} / \mathrm{ET}_{\mathrm{c}}\left(\mathrm{I}_{1}\right), 0.8 \mathrm{IW} / \mathrm{ET}_{\mathrm{c}}\left(\mathrm{I}_{2}\right)$ and $1.0 \mathrm{IW} / \mathrm{ET}_{\mathrm{c}}$ $\left(\mathrm{I}_{3}\right)$ (Table 1). Large plot technique was adopted with three replications of each treatment. Irrigation frequency was kept as 3 days' interval. Adjusted $\mathrm{FAO} \mathrm{K}_{\mathrm{C}}$ was determined for different growth stages and multiplied by evapotranspiration from reference vegetation $\left(\mathrm{ET}_{0}\right)$ to compute $\mathrm{ET}_{\mathrm{C}}$. Adjusted crop coefficient was calculated from tabulated crop coefficient as per FAO 56 method and $\mathrm{ET}_{0}$ was calculated by using Penman-Monteith equation.

$$
E T_{0}=\frac{0.408 \Delta\left(R_{n}-G\right)+\gamma \frac{900}{T+273} u_{2}\left(e_{s}-e_{a}\right)}{\Delta+\gamma\left(1+0.34 u_{2}\right)}
$$

Where,

$\mathrm{ET}_{0}$ is reference evapotranspiration [mm day 1],

$R_{n}$ is net radiation at the crop surface $\left[M J m^{-}\right.$ 2 day $^{-1}$ ],

$\mathrm{G}$ is soil heat flux density $\left[\mathrm{MJ} \mathrm{m} \mathrm{m}^{-2} \mathrm{day}^{-1}\right]$,

$\mathrm{T}$ is mean daily air temperature at $2 \mathrm{~m}$ height $\left[{ }^{\circ} \mathrm{C}\right]$,

$\mathrm{u}_{2}$ is wind speed at $2 \mathrm{~m}$ height $\left[\mathrm{m} \mathrm{s}^{-1}\right.$,

$\mathrm{e}_{\mathrm{s}}$ is saturation vapour pressure $[\mathrm{kPa}]$, $\mathrm{e}_{\mathrm{a}}$ is actual vapour pressure $[\mathrm{kPa}]$,

$\mathrm{e}_{\mathrm{s}}-\mathrm{e}_{\mathrm{a}}$ is saturation vapour pressure deficit $[\mathrm{kPa}]$,

$\Delta$ is slope vapour pressure curve $\left[\mathrm{kPa}^{\circ} \mathrm{C}^{-1}\right]$,

$\gamma$ is psychrometric constant $\left[\mathrm{kPa}^{\circ} \mathrm{C}^{-1}\right]$.

\section{Results and Discussion}

Effect of $\mathrm{N}$ levels and irrigation levels on the yield and yield contributing characters of wheat are presented in Table 2. The result showed that, the effect of fertigation level and irrigation levels gave a significant effect on plant height, ear length, number of grains per ear, number of tiller per sq. m., number of ear per sq. m., test weight, grain yield, biological yield and straw yield.

Highest plant height was observed in treatment $\mathrm{T}_{12}$ (100\% RDF-N @ 1.0 ETc) $(81.47 \mathrm{~cm})$ and the lowest plant height was observed in treatment $\mathrm{T}_{1}$ (40\% RDF-N @0.6 ETc) $(67.53 \mathrm{~cm})$ as shown in figure 1. Highest number of grains per ear was observed in treatment $\mathrm{T}_{12}(100 \%$ RDF-N @ 1.0 ETc) (33.4) and the lowest number of grains per ear was observed in treatment $\mathrm{T}_{1}$ (40\% RDF-N @0.6 ETc) (21.8) as shown in figure 2. Adequate moisture availability and fertilizer application during the whole season results the higher grains per ear in treatment combination $\mathrm{F}_{4} \mathrm{I}_{3}$.

Highest number of tiller per $\mathrm{m}^{2}$ was observed in treatment $\mathrm{T}_{12}(100 \% \mathrm{RDF}-\mathrm{N} @ 1.0 \mathrm{ETc})$ (413) and the lowest number of tiller per $\mathrm{m}^{2}$ was observed in treatment $\mathrm{T}_{1}$ (40\% RDF$\mathrm{N} @ 0.6 \mathrm{ETc})$ (287.33) as shown in figure 3. Highest grain yield was observed in treatment $\mathrm{T}_{12}$ (100 \% $\quad$ RDF-N @ 1.0 ETc) (5407.41 $\mathrm{kg} / \mathrm{ha}$ ) and the lowest grain yield was observed in treatment $\mathrm{T}_{1}$ (40\% \%DF-N @0.6 ETc) $(3374.89 \mathrm{~kg} / \mathrm{ha})$ as shown in figure 4 . 
Fig.1 Effect of fertigation levels and irrigation levels on plant height at harvest

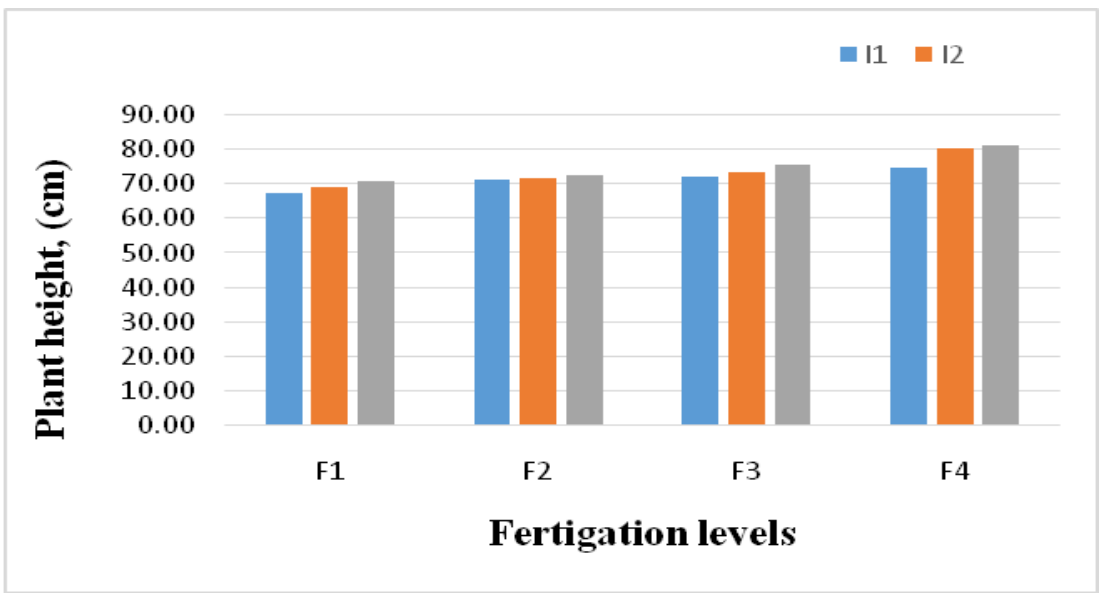

Fig.2 Effect of fertigation levels and irrigation levels on number of grains per ear

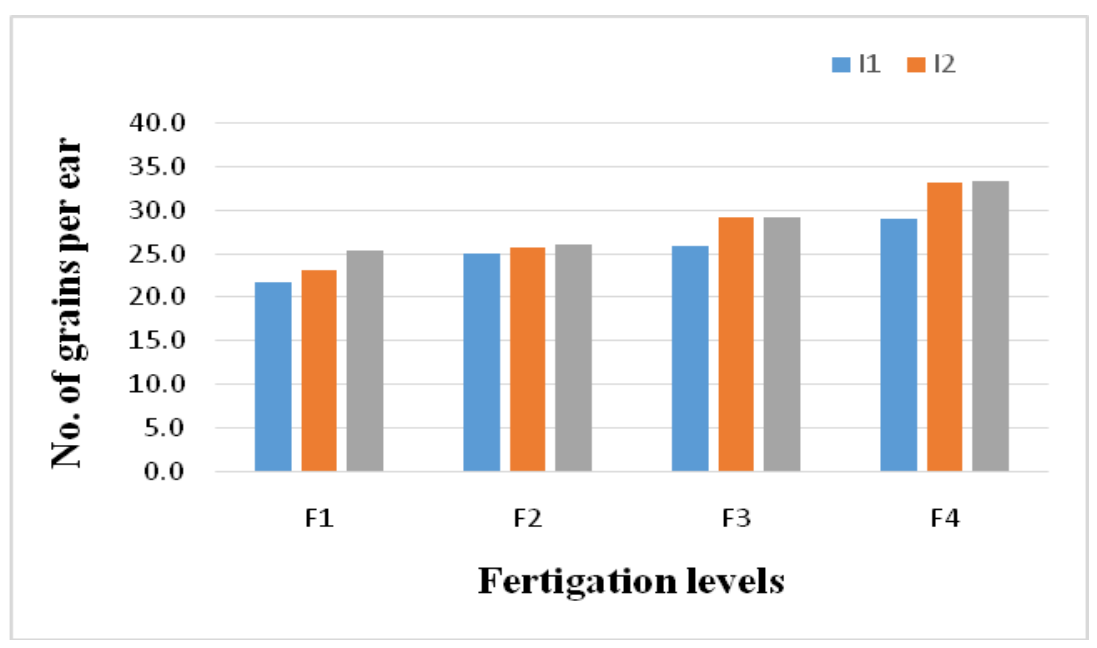

Fig.3 Effect of fertigation levels and irrigation levels on number of tiller per $\mathrm{m}^{2}$

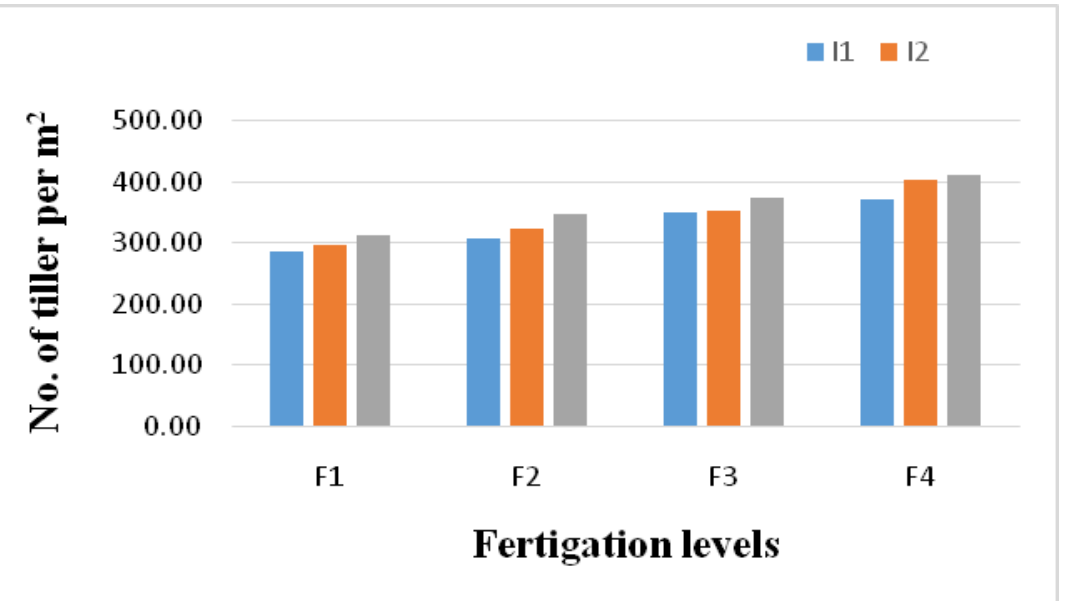


Fig.4 Effect of fertigation levels and irrigation levels on grain yield ( $\mathrm{kg} / \mathrm{ha})$

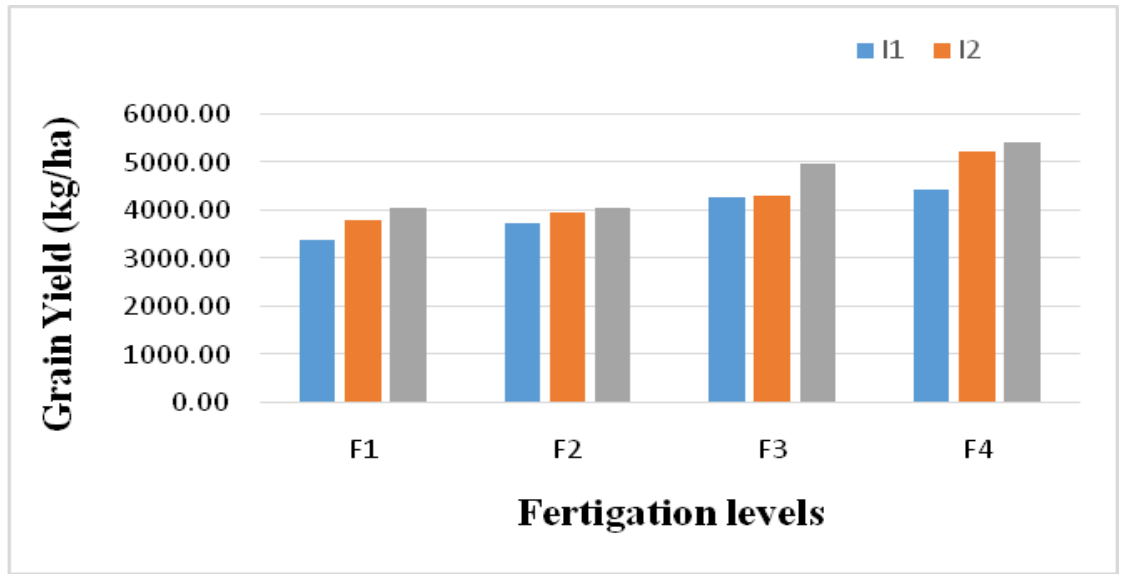

Fig.5 Fertilizer use efficiency under different treatments

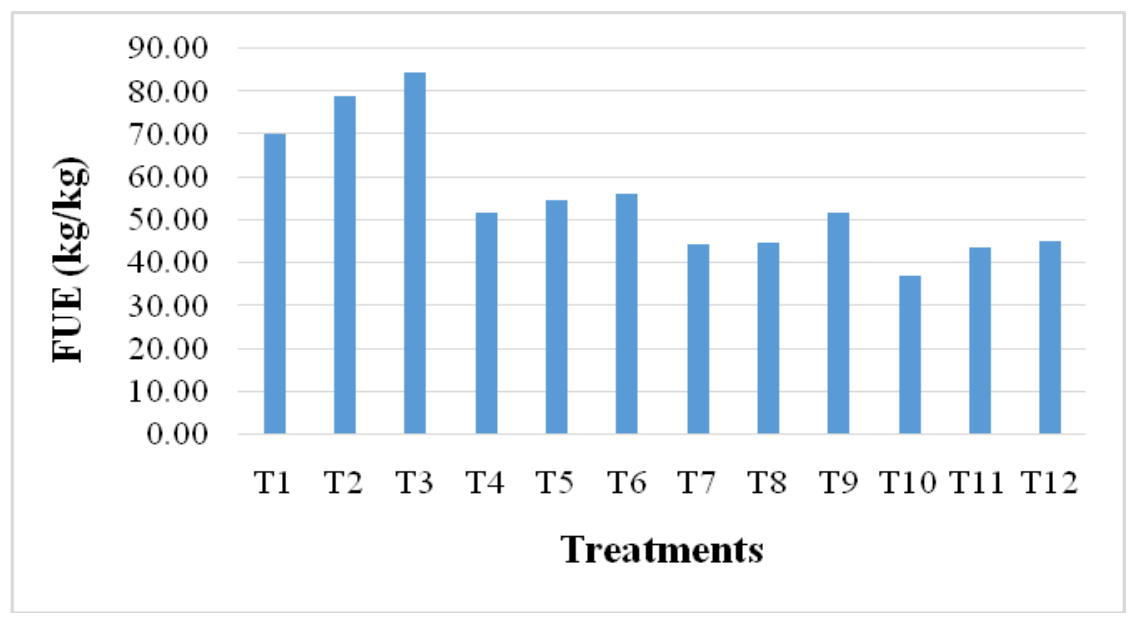

Fig.6 Water use efficiency under different treatments

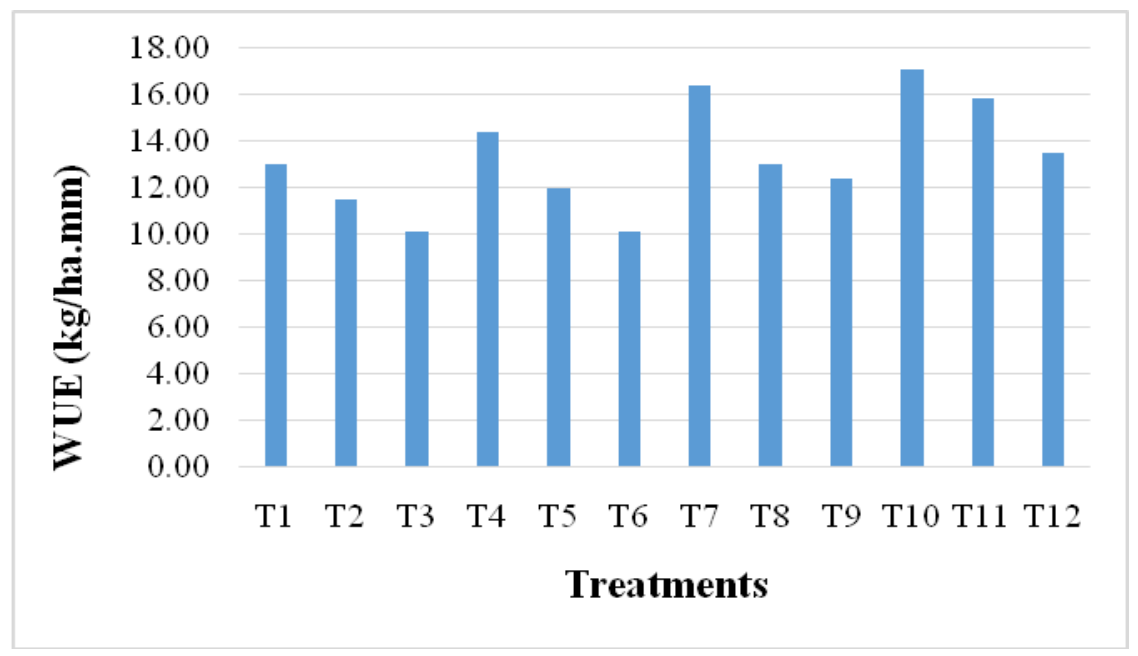


Int.J.Curr.Microbiol.App.Sci (2019) 8(6): 2519-2526

Table.1 Nitrogen schedule for wheat crop

\begin{tabular}{|c|c|c|c|c|c|c|c|c|c|}
\hline \multirow[t]{3}{*}{ DAS } & \multirow{3}{*}{$\begin{array}{c}\text { Nitrogen } \\
(\%)\end{array}$} & \multicolumn{8}{|c|}{ Recommended dose of $\mathrm{N}$-fertilizer } \\
\hline & & \multicolumn{2}{|c|}{$40 \%$ RDF -N } & \multicolumn{2}{|c|}{ 60\% RDF-N } & \multicolumn{2}{|c|}{ 80\% RDF-N } & \multicolumn{2}{|c|}{$100 \%$ RDF-N } \\
\hline & & $\begin{array}{c}\mathrm{N} \\
\mathrm{kg} / \mathrm{ha}\end{array}$ & $\begin{array}{c}\text { Urea } \\
\mathrm{kg} / \mathrm{ha}\end{array}$ & $\underset{\mathrm{kg} / \mathrm{ha}}{\mathrm{N}}$ & $\begin{array}{c}\text { Urea } \\
\mathrm{kg} / \mathrm{ha}\end{array}$ & $\begin{array}{c}\mathrm{N} \\
\mathrm{kg} / \mathrm{ha}\end{array}$ & $\begin{array}{c}\text { Urea } \\
\mathrm{kg} / \mathrm{ha}\end{array}$ & $\begin{array}{c}\mathrm{N} \\
\mathrm{kg} / \mathrm{ha}\end{array}$ & $\begin{array}{c}\text { Urea } \\
\mathrm{kg} / \mathrm{ha}\end{array}$ \\
\hline Basal & 10 & 4.8 & 10.4 & 7.2 & 15.6 & 9.6 & 20.8 & 12 & 26 \\
\hline 15 & 15 & 7.2 & 15.6 & 10.8 & 23.4 & 14.4 & 31.2 & 18 & 39 \\
\hline $16-22$ & 15 & 7.2 & 15.6 & 10.8 & 23.4 & 14.4 & 31.2 & 18 & 39 \\
\hline 23-29 & 15 & 7.2 & 15.6 & 10.8 & 23.4 & 14.4 & 31.2 & 18 & 39 \\
\hline 30-36 & 15 & 7.2 & 15.6 & 10.8 & 23.4 & 14.4 & 31.2 & 18 & 39 \\
\hline $37-43$ & 10 & 4.8 & 10.4 & 7.2 & 15.6 & 9.6 & 20.8 & 12 & 26 \\
\hline 44-50 & 10 & 4.8 & 10.4 & 7.2 & 15.6 & 9.6 & 20.8 & 12 & 26 \\
\hline 51-57 & 5 & 2.4 & 5.2 & 3.6 & 7.8 & 4.8 & 10.4 & 6 & 13 \\
\hline 58-64 & 5 & 2.4 & 5.2 & 3.6 & 7.8 & 4.8 & 10.4 & 6 & 13 \\
\hline & 100 & 48 & 104 & 72 & 156 & 96 & 208 & 120 & 260 \\
\hline
\end{tabular}


Table.2 Effect of different treatment combination on yield and yield attributing characteristics of wheat

\begin{tabular}{|c|c|c|c|c|c|c|c|c|c|c|c|c|c|}
\hline \multicolumn{2}{|c|}{ Treatment } & \multirow{2}{*}{$\begin{array}{c}\begin{array}{c}\text { Fertigation } \\
\text { levels }\end{array} \\
40 \% \text { RDF-N }\end{array}$} & \multirow{2}{*}{$\begin{array}{c}\begin{array}{c}\text { Irrigation } \\
\text { levels }\end{array} \\
0.6 \text { ETc }\end{array}$} & \multirow{2}{*}{$\begin{array}{c}\begin{array}{c}\text { Plant } \\
\text { height }\end{array} \\
67.53\end{array}$} & \multirow{2}{*}{\begin{tabular}{|c|} 
Ear length \\
\\
6.40
\end{tabular}} & \multirow{2}{*}{$\begin{array}{c}\begin{array}{c}\text { Number } \\
\text { of }\end{array} \\
\text { grains } \\
\text { per } \\
\text { ear } \\
21.8\end{array}$} & \multirow{2}{*}{$\begin{array}{c}\begin{array}{c}\text { Number } \\
\text { of }\end{array} \\
\text { tiller } \\
\text { per } \\
\text { m2 } \\
287.33\end{array}$} & \multirow{2}{*}{$\begin{array}{c}\begin{array}{c}\text { Number } \\
\text { of }\end{array} \\
\text { ear per } \\
\text { m2 } \\
242.75\end{array}$} & \multirow{2}{*}{$\begin{array}{c}\begin{array}{c}\text { Test } \\
\text { weight }\end{array} \\
48.27 \\
\end{array}$} & \multirow{2}{*}{$\begin{array}{c}\text { Grain yield } \\
3375\end{array}$} & \multirow{2}{*}{$\begin{array}{c}\begin{array}{c}\text { Biological } \\
\text { yield }\end{array} \\
\\
8764\end{array}$} & \multirow{2}{*}{$\begin{array}{c}\text { Straw yield } \\
\\
5389\end{array}$} & \multirow{2}{*}{$\begin{array}{c}\begin{array}{c}\text { Harvest } \\
\text { index }\end{array} \\
38.51\end{array}$} \\
\hline $\mathbf{T}_{1}$ & $\mathrm{~F}_{1} \mathrm{I}_{1}$ & & & & & & & & & & & & \\
\hline $\mathbf{T}_{2}$ & $\mathrm{~F}_{1} \mathrm{I}_{2}$ & $40 \%$ RDF-N & 0.8 ETc & 69.13 & 7.01 & 23.0 & 296.67 & 252.04 & 49.46 & 3792 & 9856 & 6065 & 38.62 \\
\hline $\mathbf{T}_{3}$ & $\mathrm{~F}_{1} \mathrm{I}_{3}$ & $40 \%$ RDF-N & $1.0 \mathrm{ETc}$ & 71.07 & 7.09 & 25.4 & 313.33 & 275.26 & 50.10 & 4060 & 10403 & 6343 & 39.06 \\
\hline $\mathbf{T}_{4}$ & $\mathrm{~F}_{2} \mathrm{I}_{1}$ & $60 \%$ RDF-N & 0.6 ETc & 71.4 & 6.73 & 25.1 & 307.67 & 273.88 & 49.15 & 3736 & 10495 & 6759 & 35.61 \\
\hline $\mathbf{T}_{5}$ & $\mathrm{~F}_{2} \mathrm{I}_{2}$ & $60 \% \mathrm{RDF}-\mathrm{N}$ & $0.8 \mathrm{ETc}$ & 71.8 & 7.17 & 25.8 & 323.00 & 282.70 & 49.95 & 3949 & 10819 & 6870 & 36.71 \\
\hline $\mathbf{T}_{6}$ & $\mathrm{~F}_{2} \mathrm{I}_{3}$ & $60 \%$ RDF-N & $1.0 \mathrm{ETc}$ & 72.6 & 7.29 & 26.1 & 348.33 & 285.52 & 50.27 & 4046 & 12134 & 8088 & 33.35 \\
\hline $\mathbf{T}_{7}$ & $\mathrm{~F}_{3} \mathrm{I}_{1}$ & $80 \%$ RDF-N & 0.6 ETc & 72.07 & 7.01 & 26.0 & 349.33 & 287.07 & 49.63 & 4259 & 10931 & 6671 & 38.78 \\
\hline $\mathbf{T}_{8}$ & $\mathrm{~F}_{3} \mathrm{I}_{2}$ & $80 \%$ RDF-N & $0.8 \mathrm{ETc}$ & 73.43 & 7.43 & 29.1 & 354.00 & 288.05 & 50.62 & 4296 & 12509 & 8213 & 34.47 \\
\hline $\mathbf{T}_{9}$ & $\mathrm{~F}_{3} \mathrm{I}_{3}$ & $80 \%$ RDF-N & 1.0 ETc & 75.87 & 7.78 & 29.2 & 373.67 & 315.26 & 50.92 & 4963 & 13019 & 8056 & 38.52 \\
\hline $\mathbf{T}_{10}$ & $\mathrm{~F}_{4} \mathrm{I}_{1}$ & $100 \%$ RDF-N & 0.6 ETc & 74.87 & 7.42 & 29.0 & 370.67 & 297.94 & 50.18 & 4444 & 13125 & 8681 & 34.04 \\
\hline $\mathbf{T}_{11}$ & $\mathrm{~F}_{4} \mathrm{I}_{2}$ & $100 \%$ RDF-N & 0.8 ETc & 80.60 & 7.93 & 33.1 & 404.67 & 322.57 & 52.03 & 5227 & 14028 & 8801 & 37.27 \\
\hline $\mathbf{T}_{12}$ & $\mathrm{~F}_{4} \mathrm{I}_{3}$ & $100 \%$ RDF-N & $1.0 \mathrm{ETc}$ & 81.47 & 8.13 & 33.4 & 413.00 & 337.98 & 52.59 & 5407 & 14843 & 9435 & 36.43 \\
\hline
\end{tabular}


The highest plant height, ear length, number of grains per ear, number of tiller per $\mathrm{m}^{2}$, number of ear per $\mathrm{m}^{2}$, test weight, grain yield, biological yield and straw yield were observed under treatment $\mathrm{T}_{12}(100 \%$ RDF-N @1.0 ETc). The lowest plant height, ear length, number of grains per ear, number of tiller per $\mathrm{m}^{2}$, number of ear per $\mathrm{m}^{2}$, test weight, grain yield, biological yield and straw yield were observed in treatment $\mathrm{T}_{1}(40 \%$ RDF-N@0.6 ETc).

Higher fertilizer use efficiency of $84.58 \mathrm{~kg} / \mathrm{kg}$ was observed at fertigation level $40 \%$ $\operatorname{RDF}\left(\mathrm{F}_{1}\right)$ combination with irrigation level 1.0 ETc $\left(\mathrm{I}_{3}\right)$ and the lowest fertilizer use efficiency of $37.04 \mathrm{~kg} / \mathrm{kg}$ was observed at fertigation level $100 \%$ RDF $\left(\mathrm{F}_{4}\right)$ with irrigation level 0.6 ETc $\left(\mathrm{I}_{1}\right)$ as shown in figure 5.

Higher water use efficiency $17.12 \mathrm{~kg} / \mathrm{ha}-\mathrm{mm}$ was observed at irrigation level $0.6 \mathrm{ETc}\left(\mathrm{I}_{1}\right)$ combination with fertilizer level $100 \%$ RDF $\left(F_{4}\right)$. And the lowest water use efficiency of $10.14 \mathrm{~kg} / \mathrm{ha}-\mathrm{mm}$ was observed at irrigation level 1.0 ETc with fertigation level $60 \%$ RDF-N $\left(F_{2}\right)$ as shown in figure 6.

In conclusions, the highest plant height, ear length, number of grains per ear, number of tiller per $\mathrm{m}^{2}$, number of ear per $\mathrm{m}^{2}$, test weight, grain yield, biological yield and straw yield were observed under treatment $\mathrm{T}_{12}(100$ $\%$ RDF-N @1.0 ETc). Considering the performance of drip irrigation system at fertigation level 100\% RDF and 1.0 ETc irrigation level which gave higher grain yield, straw yield, yield attributes and net return, this combination may be adopted for wheat cultivation under drip fertigation for increasing the farmers' income.

\section{References}

Bar-Yosef, B. 1999. Advances in fertigation. Advances in Agronomy. 65: 1-77.

Chauhan, R. P. S. and Yadav, B.S. 2012. Studies on crop yield responses to deficit irrigation and levels of nitrogen in wheat, water, energy and food security: call for solutions. India Water Week, New Delhi.

INCID. 1994. Drip Irrigation in India, Indian National Committee on Irrigation and Drainage. New Delhi.

Rosegrant, W. M. 1997. Water resources in the twenty-first century: challenges and implications for action, food, agriculture and the environment discussion paper 20. International Food Policy Research Institute. Washington D.C., U.S.A.

Singh, B. N., Vishwakarma, S.R and Singh, V. K. 2010. Character association and Path analysis in elite lines of wheat (Triticum aestivum L.). Plant Archives. 10: $845-847$.

Sivanappan, R. K. and Ranghaswami, M. V. 2005. Technology to take 100 tonnes per acre in Sugarcane. Kisan World. 32(10): 35-38.

\section{How to cite this article:}

Karangiya, B.A., H.H. Mashru and Vadher, H.M. 2019. Response of Wheat (Triticum aestivum L.) under Drip Fertigation System. Int.J.Curr.Microbiol.App.Sci. 8(06): 2519-2526. doi: https://doi.org/10.20546/ijcmas.2019.806.302 